Article

\title{
Gym-Goers Preference Analysis of Fitness Centers during the COVID-19 Pandemic: A Conjoint Analysis Approach for Business Sustainability
}

\author{
Ardvin Kester S. Ong 1,2,3@ , Yogi Tri Prasetyo ${ }^{1, *}$, Kerr Lorenzo Picazo ${ }^{1}$, Kim Aaron Salvador ${ }^{1}$, \\ Bobby Ardiansyah Miraja $4\left(\mathbb{D}\right.$, Yoshiki B. Kurata ${ }^{1,2,3}{ }^{(D}$, Thanatorn Chuenyindee ${ }^{1,2,5}$, Reny Nadlifatin ${ }^{6}$, \\ Anak Agung Ngurah Perwira Redi ${ }^{7}$ and Michael Nayat Young ${ }^{1}$
}

check for updates

Citation: Ong, A.K.S.; Prasetyo, Y.T.;

Picazo, K.L.; Salvador, K.A.;

Miraja, B.A.; Kurata, Y.B.;

Chuenyindee, T.; Nadlifatin, R.;

Redi, A.A.N.P.; Young, M.N.

Gym-Goers Preference Analysis of

Fitness Centers during the COVID-19

Pandemic: A Conjoint Analysis

Approach for Business Sustainability.

Sustainability 2021, 13, 10481.

https:/ /doi.org/10.3390/su131810481

Academic Editors: João Carlos de Oliveira Matias

Received: 22 August 2021

Accepted: 17 September 2021

Published: 21 September 2021

Publisher's Note: MDPI stays neutral with regard to jurisdictional claims in published maps and institutional affiliations.

Copyright: (C) 2021 by the authors. Licensee MDPI, Basel, Switzerland. This article is an open access article distributed under the terms and conditions of the Creative Commons Attribution (CC BY) license (https:/ / creativecommons.org/licenses/by/ $4.0 /)$.
1 School of Industrial Engineering and Engineering Management, Mapúa University, 658 Muralla St., Intramuros, Manila 1002, Philippines; aksong@mapua.edu.ph (A.K.S.O.); klcpicazo@gmail.com (K.L.P.); kapsalvador@mymail.mapua.edu.ph (K.A.S.); ybkurata@ust.edu.ph (Y.B.K.); earthclubz@windowslive.com (T.C.); mnyoung@mapua.edu.ph (M.N.Y.)

2 School of Graduate Studies, Mapúa University, 658 Muralla St., Intramuros, Manila 1002, Philippines

3 Department of Industrial Engineering, Faculty of Engineering, University of Santo Tomas, España Blvd., Manila 1015, Philippines

4 Faculty of Business and Economics, Universitas Surabaya, Surabaya 60111, Indonesia; bobard.m@outlook.com

5 Department of Industrial Engineering and Aviation Management, Navaminda Kasatriyadhiraj Royal Thai Air Force Academy, Bangkok 10220, Thailand

6 Department of Information Systems, Institut Teknologi Sepuluh Nopember, Kampus ITS Sukolilo, Surabaya 60111, Indonesia; reny.nadlifatin@gmail.com

7 Industrial Engineering Department, BINUS Graduate Program-Master of Industrial Engineering, Bina Nusantara University, Jakarta 11480, Indonesia; wira.redi@binus.edu

* Correspondence: ytprasetyo@mapua.edu.ph; Tel.: +63-(2)-8247-5000 (ext. 6202)

Abstract: The COVID-19 pandemic has had a great impact on the fitness centers industry. The purpose of this study is to analyze the preference of gym-goers on fitness centers in the Philippines during the COVID-19 pandemic by utilizing a conjoint analysis approach. One thousand gymgoers voluntarily participated in this study and answered 22 queries created from the orthogonal design. The results indicated that Price was the highest attribute considered $(21.59 \%)$, followed by Ventilation (17.56\%), Service (16.59\%), Trainer (14.63\%), Payment Method (11.95\%), Operating Hours $(8.90 \%)$, and Login $(8.70 \%)$. The results also indicated that comfort, security, and fitness center services were the main aspects that gym-goers would consider as their main preference. The study highlighted how gym-goers are sensitive to the price set by the fitness centers. Moreover, due to the COVID-19 pandemic, ventilation and size are considered highly important attributes among gym-goers. Comfort, safety, and security are the main consideration to have sustainable fitness centers during and even after the COVID-19 pandemic. The outcome of this study may benefit fitness centers and increase their business market by considering the preference of customers. Finally, the result of this study can be utilized by fitness centers to promote a generalized fitness center for gym-goers of different generations, statuses, and even socioeconomic status during and even after the COVID-19 pandemic.

Keywords: conjoint analysis; fitness center; gym-goers; COVID-19; business sustainability; Philippines

\section{Introduction}

The number of fitness centers has increased throughout the years. Along with the increase of fitness centers is the significant increase of gym goers [1]. This is due to how aware people are of the effects of their age on their physical activities [2]. According to the International Health, Racquet, and Sportsclub Association (IHRSA) [3], gym-goers are comprised of 33\% from Generation Y, also known as Millennials (born between 1980 
and 1999), followed by 24\% from Generation X (born between 1965 and 1979), 22\% from Baby Boomers (born between 1945 and 1964), 14\% from Generation Z (born in years 2000 and later), and 7\% from the Silent Generation (born before 1945). This shows how fitness centers are utilized by any generation and have a great market.

In 2018, fitness centers gained revenues that exceeded $\$ 2$ billion USD and continued to rise to $\$ 96$ billion USD in 2019 [4]. One reason for the growth is generational preferences when it comes to fitness. The IHRSA [3] stated that Millennials and Generation Z participate more in group activities, while Generation $X$ and Boomers tend to utilize the strengthening and cardio-related equipment. This has led people to have multiple gym memberships, since preferences are not fully available in one fitness center for them [3]. This has also led to an increase in fitness centers [5]. In addition, Mordor Intelligence [6] stated that people are willing to train and spend on health and fitness-related markets.

Numerous studies have shown that fitness centers have been strategizing throughout the years to encourage people to go to gyms. The study of Avourdiadou and Theodorakis [7] focused on loyalty among novice and experienced customers in fitness centers. Their result showed that service quality had the most significant effect on satisfaction. Moreover, Hooker et al. [8] focused on factors affecting the termination of memberships among gym-goers. It showed that people who were unhealthy and psychologically unwell highly terminated their membership. Their study suggested that intervention and even program expansion or other factors should be taken into consideration. In addition, Bagir and Altinig [9] studied the reasons for preferences of fitness centers in Sakarya. Their results only showed that people preferred gyms due to recommendations and broadly stated that the gym met customers' expectations. However, these studies were done before the COVID-19 pandemic.

During the COVID-19 pandemic, the government implemented lockdowns of what were considered non-essential. Among these were fitness centers that were highly profitable before the COVID-19 pandemic [4]. The fear of people regarding the COVID-19 virus led to the change in their lifestyle-having to focus on health, while staying at home, and sanitize frequently. The behavior of people during the COVID-19 pandemic changed as health became the priority. Therefore, the exploration of the preferences of gym-goers during the COVID-19 pandemic should be explored. What did fitness enthusiasts prefer in the fitness centers during the COVID-19 pandemic? As fitness centers progress, market sales increases. However, with the strict implementation of lockdowns, the decrease of gym-goers was evident. It could increase the affirmation to go to fitness centers if the preferences of people are available.

Even with the willingness to train and spend on health and fitness, gym-goers were not able to utilize the fitness centers during the COVID-19 pandemic. This is because fitness centers around the world were forced to shut down due to the COVID-19 pandemic [10]. This led fitness centers to advertise their programs online to continue with business [6]. However, with the current protocols implemented such as constant sanitation, social distancing, and wearing protecting equipment such as masks, fitness centers opened with minimal and controlled attendees [11]. With that, the preference of these customers should be taken into consideration to cater to their needs, maintain a good relationship, and increase market revenue.

Although there were numerous articles that dealt with fitness centers, the focus was on the market and trends side. It is seen that the preference of gym-goers, especially during the COVID-19 pandemic, is underexplored. Taking into consideration the study by Garcia-Fernandez et al. [12] from Spain, they only focused on service convenience and perceived quality. However, their study focused only on low-cost fitness centers. In Finland, Ruotsalainen et al. [13] only focused on physical activities and aerobic fitness in adolescents. In the United Kingdom, Birch [14] considered only the adaptive evolution of fitness to gene change. However, the result of their study showed that inclusive fitness is not accurate for predicting changes. Faulkner [15] from Canada dealt with loyalty points being an incentive program for gym-goers. It was seen that gym-goers were welcoming to 
the loyalty incentives; however, their study recommended determining the optimal design to maintain customers' preferences and increase satisfaction.

One way to measure preferences among customers is the utilization of conjoint analysis [16-19]. This tool is widely used in marketing and consumer research [20-22]. Conjoint analysis has been utilized in different aspects of measuring preference such as food [23-25], urban planning and designs [17,26,27], and even in physical activities [28]. However, there are no studies that dealt mainly on customer preferences of fitness centers, specifically during COVID-19.

This study aimed to analyze the preference of gym-goers of the different fitness centers in the Philippines. Specifically, this study utilized conjoint analysis using orthogonal design to measure the preference and attributes based on evaluation of the complete set-up [21,29]. To determine the best combination of fitness centers, this study considered attributes such as Prices, Mode of Payment, Trainer, Ventilation, Logins, Operating Hours, and Fitness Center Size. This study is the first study that utilized a conjoint analysis approach to analyze fitness center attributes during the COVID-19 pandemic. The outcomes of this study could benefit fitness centers and increase their business market by considering the preferences of customers. Being able to cater to people's preferences would enhance engagement such as going to fitness centers. Moreover, the study covered demographics of different generations and thus has a holistic point of view. The results may be utilized by fitness centers to promote a generalized fitness center for gym goers of different generations during and even after the pandemic.

This paper is organized as follows. Section 1 contains the background of the study, related studies regarding fitness centers, research gap, discussion of tool utilized, objectives of the study, and contribution. Section 2 discusses the methodology, participants, the conjoint design and how it was conceptualized, and statistical analysis. Section 3 covers the results of the study. Section 4 discusses the results and implications of this study compared to other studies. Section 5 discusses the conclusion of this study.

\section{Literature Review}

\subsection{Conjoint Analysis}

Conjoint analysis is a tool widely utilized in consumer behavior [20-22,29]. It operates by having the respondents choose among different combinations of levels from chosen attributes considered in the study. From the rating, the results of the conjoint analysis indicate which attributes are considered to be important and significant from a 7-point Likert scale. The results prompt the rankings or ratings of the consumers from a hypothetical service that is presented from the survey questionnaire. Studies such as food and beverages preferences, such as milk and tea [23,30], online learning attributes [21,31,32], park preferences [17,27], musical instruments [22], education [33,34], public e-services [26], and even health risks and vaccine preferences $[35,36]$ have been conducted. Therefore, conjoint analysis as a tool for evaluating the complete set-up of group attributes highlights consumer preferences and can lead to businesses being able to understand customer preference and, if delivered, can lead to customer satisfaction [30]. Moreover, Ong et al. [30] indicated that customer satisfaction, by providing services of their preference, can lead to customer retention. This eventually may provide a concept among business owners on how to strategize their services to provide a sustainable business set-up for their customers.

\subsection{Fitness Centers}

Studies relating to fitness centers have been underexplored. The most recent studies regarding fitness centers dealt with only low-cost fitness centers available in Spain [12], and they focused only on aerobics and physical activities in Finland [13], fitness gene change in the United Kingdom [13], and loyalty points offered in fitness centers at Canada [15]. There were no studies that explored the fitness centers in the Philippines before and during the COVID-19 pandemic. 
Fitness centers are of importance as they highlight and promote healthy living among individuals through exercise and workouts. Especially in this unprecedented time, the health of an individual is very crucial. Therefore, the promotion to continue with fitness center availability during the COVID-19 pandemic is critical. Taking into consideration that fitness centers are a service-providing business, it was one of many businesses that was challenged during the COVID-19 pandemic. The COVID-19 pandemic and lockdowns challenged owners and managers to strategize for customers to consider their service offered.

During the lockdown, people have been relieved of their jobs due to slow business movement or even bankruptcy. Therefore, one of the important attributes service providers consider should be the price. As indicated by the studies of Kosenko and Rahtz [37] and Rao and Sieben [38], the price range is crucial in any business. The consumer always tends to consider lower price range service providers with at par business offerings. The consideration of prices among fitness centers may be considered as a significant attribute by the consumers, especially for those without a source of income during the COVID-19 pandemic. Therefore, strategies among prices should be considered by the business sector.

Ventilation is an attribute present in any fitness center. As indicated from the study of Blocken et al. [39], gym-goers secrete a lot of carbon dioxide during workouts or exercise. With the current pandemic, this may be considered dangerous if ventilation is not available due to particles from the exhaust of a client. Control strategies help fitness centers to showcase safety and promote physical activities [40]. In addition, strategies such as bundles or promotions for gym-goers may be considered. These may be capitalized by business owners and managers during the COVID-19 pandemic. As suggested by Woolf [41], making the customer feel special tends to heighten their satisfaction, such as VIP services. Moreover, heightened security and safety should be considered by businesses as suggested by different studies [42-46].

\subsection{Business Strategies during the COVID-19 Pandemic}

Business strategies have been explored during the COVID-19 pandemic as it is the new normal living condition. Leon-Quismondo et al. [47] indicated that there is a growing interest in the services provided by fitness centers, wherein management and their services should be optimized. Best practices have been considered in fitness centers due to the increase in gym-goer engagements. The results of the study [47] showed that customer service, offered service, marketing, facilities, and general terms and conditions were the best practices recommended by the managers towards fitness centers. However, there were no indications regarding customer satisfaction or preference to prevalently justify the plan of action among the characteristics considered.

During the COVID-19 pandemic, the old strategies provided by managers and businesses should be changed when the new normal conditions are considered. Mahdi and Nassar [48] discussed how knowledge in the business management aspect is crucial to accomplish a sustainable competitive advantage. Knowledge such as knowing what customers prefer during the COVID-19 may be utilized to strategize a business. When customers' preferences are being catered to, then customer satisfaction increases [30]. Moreover, Sahabuddin et al. [49] indicated that customer satisfaction is a prevailing aspect in the business sector. This will therefore lead to customer retention and eventually to profitability and business sustainability.

Pongsakornrungslip et al. [50] also discussed how brand recognition should be made, as strong brands and proper business management may lead to survival during the COVID19 pandemic. For businesses to know how to manage their respective sectors, the preferences of customers should be taken into consideration in order to present the option among customers. Therefore, it could be deduced that during the COVID-19 pandemic, businesses must be able to create a new strategy from knowledge such as customer preferences. This will help businesses not only survive but engage with customers as well. 


\section{Methodology}

\subsection{Participant}

One thousand (1000) gym-goers voluntarily participated in this study through convenience sampling. The respondents considered were only people who constantly went to the gym before and during the COVID-19 pandemic in the Philippines. The responses were collected online from December 2020 to March 2021. A social media platform was utilized to make the survey available for anyone to answer. Specifically, the survey was made available for anyone who goes to the gym, posted in different gym-goer groups. A statement "click yes to confirm that you go to the gym before and during the COVID-19 pandemic" prompted the questionnaire for this study. Otherwise, they were not be able to answer the survey form. Sethuraman et al. [51] suggested that responses collected online and with the COVID-19 pandemic would be sufficient for conjoint analysis. The respondents were asked to fill out a consent form before answering the questionnaire for this study.

\subsection{Research Conceptualization and Conjoint Design}

This study adopted a business framework (Figure 1) from Geissdoerfer et al. [52]. The framework was created for a sustainable business model that incorporated pro-active multistakeholder management. The adapted model also considers the creation of monetary and non-monetary value and the long-term perspective of a business. Sustainability refers to the state of achieving the needs of the current generation and meeting without compromising the needs of the future generation. Thus, the design in this study considered attributes that are present in the fitness centers, generally, before and even after the COVID-19 pandemic.

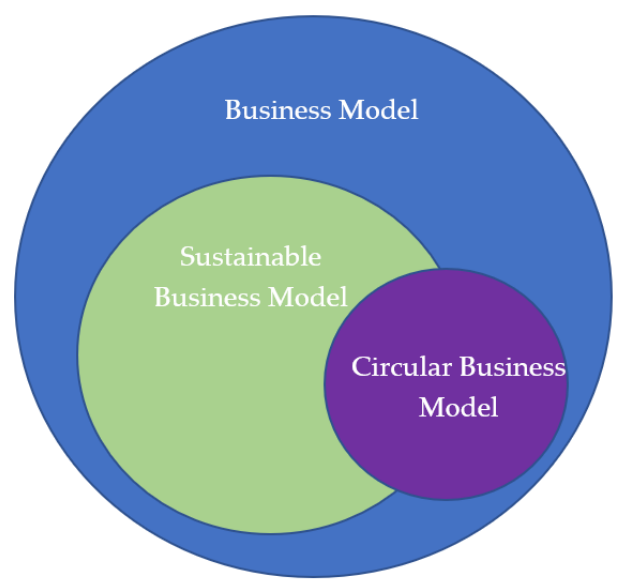

Figure 1. Business Model Framework adopted from Geissdoerfer et al. [52].

Adapting the idea from the study of Mahdi and Nassar [48], knowledge on the management process during the COVID-19 pandemic may lead to success in attaining a sustainable business strategy. The built-on social, economic, and human capital can create a strategic advantage in any business. With that, the business model framework considered in this study considered both monetary and non-monetary value to build a sustainable business. Like any other business, the economic aspect is crucial to have continuous growth through profit. Moreover, the model utilized by Sushil and Anbarasan [53] considered the same strategy and incorporated the technology aspect for sustainable operational complexity. Their model highlights the strategic overview with social value expenditure as the main factor for sustainable business practice. Moreover, the sharing economy could also be part of the monetary aspect of the business model. The one developed by Yang and Xia [54] highlighted pricing strategies for business sustainability. In addition, the model utilized by Ying et al. [55] highlighted how restructuring, rebranding, and reconsideration of the current business should be done for efficiency. Lastly, the model considered by Ahmad et al. [56] focused on service-related in accordance to sales. Their 
model highlighted that leadership, adaptive behavior, and motivation together with the ability to engage and highlights opportunity can result in service-sales ambidexterity.

Overall, it can be seen that to have a sustainable business, strategies involving replanning, leadership, motivated salespersons, and consideration of social, economic, and human capital could create a sustainable business during and even after the COVID-19 pandemic. Similar to Sahabuddin et al. [49], the satisfaction of customers is a prevailing aspect. Moreover, Ong et al. [30] stated that preferences can lead to customer satisfaction and thus customer retention. With that, different attributes that were considered in this study were of general representation in the service provided by fitness centers during the COVID-19 pandemic and may also be present even after the pandemic ends. This can then lead to the proper strategies among businesses during and even after the COVID-19 pandemic.

The attributes and design of this research underwent conceptualization as presented in Figure 2. This study considered the different attributes in the preparation stage from which different studies were considered to formulate the attributes and levels. Due to the COVID-19 pandemic, this study focused on attributes present in the Philippines where this was conducted. The implementation stage ran a preliminary test to determine the validity of the conjoint analysis orthogonal design. According to Hair [57], a Pearson's Rvalue greater than or equal to 0.70 indicates that the orthogonal design may be considered acceptable $[30,31,46]$. This study had an initial result of 0.912 - considered to be a high relationship among the responses and attribute of preference. The final stage involved the questionnaire distribution, generation of results, and analysis and interpretation.

\begin{tabular}{|c|c|c|}
\hline Preparation Stage & Implementation Stage & Final Stage \\
\hline $\begin{array}{ll}\text { - } & \text { Brainstorming } \\
\text { - } & \text { Generation of } \\
\text { Orthogonal Design } \\
\text { - } \\
\text { Questionnaire } \\
\text { Development }\end{array}$ & $\begin{array}{ll}\text { Test Run } \\
\text { - } & \text { Preliminary } \\
\text { Questionnaire } \\
\text { Distribution } \\
\text { - } \\
\text { Generation of Result } \\
\text { (Pearson's } R \geq 0.7 \text { ) }\end{array}$ & $\begin{array}{ll}\text { - } & \text { Questionnaire } \\
& \text { Distribution } \\
\text { - } & \text { Generation of Result } \\
\text { - } & \text { Analysis and } \\
& \text { Interpretation }\end{array}$ \\
\hline
\end{tabular}

Figure 2. Research Conceptualization.

This study considered 7 attributes gathered from related studies. The first attribute considered was Price in Philippines Pesos (PhP). The prices considered were less than $1000 \mathrm{PhP}$ (<\$20 USD), 1001-2000 PhP (\$21-\$41.50 USD), and greater than $2000 \mathrm{PhP}$ (>\$2 USD). The prices were considered because price basically has a positive influence on the purchase intentions of customers $[30,58]$. With the price, Payment Method was considered as the second attribute. Bezhovski [59] indicated that there are different payment methods available, among which are credit cards and cash as the traditional methods. On the other hand, the increase of e-commerce has led to the utilization of online payment methods [59].

The third attribute considered was the Trainer, among which were one-on-one, oneto-many, and many-to-one. This was considered because fitness does not have a hard guideline [60]. Acquaviva [60] indicated that trainers should consider the individual status and capabilities for their fitness programs. In addition, De Lyon et al. [61] indicated that professionals in the fitness centers must know what is good for the clients. However, due to the lack of employees in fitness centers [3], sometimes fitness centers take into consideration many-to-one or one-to-many instead of the traditional one-on-one.

The fourth attribute was Ventilation. Either fans, fully airconditioned, or a mix of both were the levels considered. Ambrosino [62] indicated that working out or doing exercise demands respiration. This is one reason why ventilation is important. It was also indicated by Blocken et al. [39] that aerosols and particles were measured to be present in fitness centers with 35 gym goers, especially during the COVID-19 pandemic. It was advised that ventilation be taken into consideration [39].

The fifth attribute considered was the Login, either manually, using QR codes, or swiping or tapping. Adhatrao et al. [63] indicated that the levels considered are the currently utilized logins for different systems. In addition, Operating Hours was also 
considered as the sixth attribute. Fitness centers try to consider their market, having a lot of customers from the working generations already. It is best to be able to cater to their needs to increase revenue [3]. With that, 6 a.m. -10 p.m., 9 a.m. to 9 p.m., and 24 h operating hours were considered as the different levels. Lastly, Service was considered. To cater to the preference of the gym-goers, VIP, regular, and premium services were considered.

In summary, Table 1 represents the 7 attributes considered in this study. The attributes considered were the Prices ( $<1000 \mathrm{PhP}$ or $>\$ 20$ USD, 1001-2000 PhP or \$21-\$41.50 USD, $>2000 \mathrm{PhP}$ or $>$ \$2 USD), Payment Method (cash, online payment, or credit card), Trainer (one-on-one, one-to-many, many-to-one), Ventilation (fans, airconditioned, airconditioned with fans), Login (manual, QR code, swipe/tap), Operating Hours ( 24 h, 6 a.m.-10 p.m., 9 a.m.-9 p.m.), and Service (regular, premium, or VIP).

Table 1. Attributes for Fitness Centers.

\begin{tabular}{cc}
\hline Attributes & Levels \\
\hline Price & $<1000 \mathrm{PhP}(<\mathbf{2 0}$ USD) \\
& $1001-2000 \mathrm{PhP}(\$ 21-\$ 41.50$ USD $)$ \\
& $>2000 \mathrm{PhP}(>\$ 42$ USD) \\
\hline Payment Method & Cash \\
& Online payment \\
Credit card \\
\hline Trainer & One-on-one \\
& One-to-many \\
& Many-to-one \\
\hline Ventilation & Fans \\
& Airconditioned \\
& Airconditioned and fans (mixed) \\
\hline Login & Manual \\
& QR code \\
& Swipe $/$ tap \\
\hline Operating Hours & 24 h \\
& 6 a.m. to 10 p.m. \\
& 9 a.m. to 9 p.m. \\
\hline Service & Regular \\
& Premium \\
& VIP \\
\hline
\end{tabular}

\subsection{Statistical Analysis}

The conjoint analysis with the orthogonal design was generated using SPSS 25. There was a total of 22 stimuli generated by the SPSS. The orthogonal design was utilized to have a reasonable number of stimuli that the participants evaluated with 2 holdouts considered in this study [30,31]. The different stimuli were evaluated using a 7-point Likert scale with a range from 1 as "strongly disagree" to 7 as "strongly agree".

\section{Results}

Presented in Table 2 are the demographics of this study. From the statistics, it can be seen that 21\% were enrolled in Anytime Fitness, 13\% in Fitness first, 5\% in Gold's Gym, 19\% in Pound for Pound Fitness, 2\% in Philippine Sports Performance, 3\% in Bakal Gym (low-cost public gyms), 1\% in each of Fit and Flow, Focus Athletics, Home Gym, Kinetix Lab, One Fitness Horizon, Own Gym, Prime Fitness, and Tipness Gym. The fitness center in the demographics presents the general fitness centers available in the Philippines. Moreover, $29 \%$ were planning to enroll in gyms even during the COVID-19 pandemic. The huge percentage from the demographics shows how sustainable the fitness centers are and that people still plan to continue to go despite the condition. 
Table 2. Demographics (N: 1000 respondents).

\begin{tabular}{|c|c|c|c|}
\hline Characteristics & Category & $\mathbf{N}$ & $\%$ \\
\hline \multirow{15}{*}{ Gym } & Anytime Fitness & 210 & $21 \%$ \\
\hline & Bakal Gym & 30 & $3 \%$ \\
\hline & Fit and Flow & 10 & $1 \%$ \\
\hline & Fitness First & 130 & $13 \%$ \\
\hline & Focus Athletics & 10 & $1 \%$ \\
\hline & Gold's Gym & 50 & $5 \%$ \\
\hline & Home Gym & 10 & $1 \%$ \\
\hline & Kinetix Lab & 10 & $1 \%$ \\
\hline & Planning to enroll & 290 & $29 \%$ \\
\hline & One fitness horizon & 10 & $1 \%$ \\
\hline & Own gym & 10 & $1 \%$ \\
\hline & $\begin{array}{l}\text { Philippine Sports } \\
\text { Performance }\end{array}$ & 20 & $2 \%$ \\
\hline & Pound For Pound Fitness & 190 & $19 \%$ \\
\hline & Prime fitness & 10 & $1 \%$ \\
\hline & Tipness Gym & 10 & $1 \%$ \\
\hline \multirow{4}{*}{ Age } & $15-24$ & 700 & $70 \%$ \\
\hline & $25-34$ & 190 & $19 \%$ \\
\hline & $35-44$ & 70 & $7 \%$ \\
\hline & $45-54$ & 40 & $4 \%$ \\
\hline \multirow{5}{*}{ Employment Status } & Entrepreneur & 50 & $5 \%$ \\
\hline & Full Time Employment & 410 & $41 \%$ \\
\hline & Part Time Employment & 80 & $8 \%$ \\
\hline & Student & 400 & $40 \%$ \\
\hline & Unemployed & 60 & $6 \%$ \\
\hline
\end{tabular}

In addition, the demographics were divided as follows: 70\% from 15-24 years old, $19 \%$ from $25-34$ years old, $7 \%$ from $35-44$ years old, and $4 \%$ from $45-54$ years old. The respondents were comprised of $5 \%$ entrepreneurs, $41 \%$ full-time employees, $8 \%$ part-time employees, and $40 \%$ students. This is similar to the demographics from the study of Bagir and Altinig [8], wherein the majority of demographics that went to fitness centers came from the 15-24 year old categories. Moreover, the study indicated that the majority of the respondents had their own goals as to why employment status ranged from students to fully employed [9].

Presented in Tables 3 and 4 are the utilities and the average importance scores of fitness centers during the COVID-19 pandemic, respectively. Based on the results, Price had the highest score (21.59\%) followed by Ventilation (17.56\%), Service (16.59\%), Trainer $(14.63 \%)$, and Payment Mode $(11.95 \%)$, and the lowest scores were for Operating Hours $(8.90 \%)$ and Login $(8.78 \%)$. Therefore, the combination that was most preferred with a score of 0.657 was less than $1000 \mathrm{Php}$ (\$20 USD), cash as the payment method, one-on-one training, fully airconditioned fitness center, utilizing swap or tap login, $24 \mathrm{~h}$ operation, and VIP service. On the other hand, the least preferred, with a score of -0.798 , was greater than $2000 \mathrm{Php}$ (>\$42 USD), credit card as the payment method, one-to-many-training, fans as the ventilation, manual logins, 9 a.m. to 9 p.m. operating hours, and regular services offered.

Taking the results into consideration, the Price less than a thousand pesos or \$20 USD was the most preferred. Fully airconditioned was the second preferred for Ventilation and having VIP Service was third. In addition, one-on-one training was preferred compared to training in groups. Lastly, approximately the same score was considered for Operating Hours as $24 \mathrm{~h}$ available and Swipe or Tap system for the Login. Further discussion of the results is presented in the discussion section. 
Table 3. Utilities.

\begin{tabular}{|c|c|c|c|}
\hline Attributes & Level & Utility Estimates & Std. Error \\
\hline \multirow[t]{3}{*}{ Price } & \multirow{3}{*}{$\begin{array}{c}<1000 \mathrm{PhP}(<\$ 20 \text { USD }) \\
1001-2000 \mathrm{PhP}(\$ 21-\$ 41.50 \\
\text { USD }) \\
>2000 \mathrm{PhP}(>\$ 42 \mathrm{USD})\end{array}$} & 0.121 & 0.042 \\
\hline & & 0.072 & 0.042 \\
\hline & & -0.193 & 0.042 \\
\hline \multirow[t]{3}{*}{ Payment Method } & Cash & 0.059 & 0.042 \\
\hline & Online payment & 0.056 & 0.042 \\
\hline & Credit card & -0.115 & 0.042 \\
\hline \multirow[t]{3}{*}{ Trainer } & One-on-one & 0.116 & 0.042 \\
\hline & One-to-many & -0.097 & 0.042 \\
\hline & Many-to-one & -0.019 & 0.042 \\
\hline \multirow[t]{3}{*}{ Ventilation } & \multirow{3}{*}{$\begin{array}{c}\text { Fans } \\
\text { Fully airconditioned } \\
\text { Airconditioned and fans } \\
\text { (mixed) }\end{array}$} & -0.106 & 0.042 \\
\hline & & 0.150 & 0.042 \\
\hline & & -0.044 & 0.042 \\
\hline \multirow[t]{3}{*}{ Login } & Manual & -0.063 & 0.042 \\
\hline & QR code & -0.001 & 0.042 \\
\hline & Swipe/tap & 0.064 & 0.042 \\
\hline \multirow[t]{3}{*}{ Operating Hours } & $24 \mathrm{~h}$ & 0.054 & 0.042 \\
\hline & 6 a.m. to 10 p.m. & 0.022 & 0.042 \\
\hline & 9 a.m. to 9 p.m. & -0.076 & 0.042 \\
\hline \multirow[t]{4}{*}{ Service } & Regular & -0.148 & 0.042 \\
\hline & Premium & 0.056 & 0.042 \\
\hline & VIP & 0.093 & 0.042 \\
\hline & (Constant) & 5.257 & 0.030 \\
\hline
\end{tabular}

Table 4. Averaged Importance Score.

\begin{tabular}{cc}
\hline Importance Values & Score \\
\hline Price & 21.585 \\
Payment Mode & 11.951 \\
Trainer & 14.634 \\
Ventilation & 17.561 \\
Login & 8.780 \\
Operating Hours & 8.902 \\
Service & 16.585 \\
\hline
\end{tabular}

Moreover, Table 5 presents the correlation results of this study. According to Hair [57] and Ong et al. [30], the Pearson's R-value indicates the relationship of the responses and the attributes in this study. From the results, it could be seen that Pearson's $\mathrm{R}$ had a value of 0.979 , indicating a high relationship $[30,31,57]$. The Kendall's Tau presents the validity and reliability of the constructs [31,57]. Hair [57] indicated that Kendall's Tau and Pearson's R-value should have a value greater than 0.70 to be considered acceptable. Moreover, Kendall's Tau Holdout had a value of 1.00, indicating that there was internal consistency among the responses gathered for this study. Lastly, the different combinations considered in this study are ranked in Table 6. The ranking shows the most preferred as ranked 1 (combination 3 ) and the least preferred ranked 22 (combination 8). 
Table 5. Correlation.

\begin{tabular}{ccc}
\hline & Value & Significance \\
\hline Pearson's R & 0.979 & 0.00 \\
Kendall's Tau & 0.882 & 0.00 \\
Kendall's Tau Holdout & 1.000 & 0.00 \\
\hline
\end{tabular}

Table 6. Stimulus Rank.

\begin{tabular}{|c|c|c|c|c|c|c|c|c|c|}
\hline Combination & Price & $\begin{array}{l}\text { Mode of } \\
\text { Payment }\end{array}$ & Trainer & Ventilation & Login & Operation Hours & Service & Total & Rank \\
\hline 1 & $\begin{array}{l}>2000 \mathrm{PhP} \\
\text { (>\$42 USD) }\end{array}$ & Cash & Many-to-one & $\begin{array}{c}\text { Mixed } \\
\text { ventilation }\end{array}$ & QR code & 6 a.m. to 10 p.m. & $\begin{array}{l}\text { Regular } \\
\text { service }\end{array}$ & -0.324 & 19 \\
\hline 2 & $\begin{array}{c}1001-2000 \mathrm{PhP} \\
(\$ 21-\$ 41.50 \\
\text { USD) }\end{array}$ & Online & Many-to-one & $\begin{array}{c}\text { Fully } \\
\text { airconditioned }\end{array}$ & QR code & 9 a.m. to 9 p.m. & $\begin{array}{l}\text { Regular } \\
\text { service }\end{array}$ & 0.034 & 12 \\
\hline 3 & $\begin{array}{l}<1000 \mathrm{PhP} \\
(<\$ 20 \mathrm{USD})\end{array}$ & Online & Many-to-one & $\begin{array}{c}\text { Fully } \\
\text { airconditioned }\end{array}$ & Swipe/tap & 6 a.m. to 10 p.m. & VIP service & 0.487 & 1 \\
\hline 4 & $\begin{array}{l}<1000 \mathrm{PhP} \\
(<\$ 20 \text { USD) }\end{array}$ & Online & One-on-one & Fans & QR code & 9 a.m. to 9 p.m. & $\begin{array}{l}\text { Premium } \\
\text { service }\end{array}$ & 0.166 & 5 \\
\hline 5 & $\begin{array}{c}1001-2000 \mathrm{PhP} \\
(\$ 21-\$ 41.50 \\
\text { USD) }\end{array}$ & Online & Many-to-one & Fans & QR code & $24 \mathrm{~h}$ & $\begin{array}{l}\text { Regular } \\
\text { service }\end{array}$ & -0.092 & 15 \\
\hline 6 & $\begin{array}{l}<1000 \mathrm{PhP} \\
(<\$ 20 \text { USD })\end{array}$ & Credit card & One-to-many & Fans & Manual & 6 a.m. to 10 p.m. & $\begin{array}{l}\text { Regular } \\
\text { service }\end{array}$ & -0.386 & 20 \\
\hline 7 & $\begin{array}{l}>2000 \mathrm{PhP} \\
(>\$ 42 \text { USD) }\end{array}$ & $\begin{array}{l}\text { Online } \\
\text { payment }\end{array}$ & One-on-one & $\begin{array}{c}\text { Mixed } \\
\text { ventilation }\end{array}$ & Manual & $24 \mathrm{~h}$ & VIP service & 0.019 & 13 \\
\hline 8 & $\begin{array}{l}>2000 \mathrm{PhP} \\
(>\$ 42 \text { USD) }\end{array}$ & $\begin{array}{l}\text { Online } \\
\text { payment }\end{array}$ & One-to-many & $\begin{array}{c}\text { Mixed } \\
\text { ventilation }\end{array}$ & Manual & 9 a.m. to 9 p.m. & $\begin{array}{l}\text { Regular } \\
\text { service }\end{array}$ & -0.565 & 22 \\
\hline 9 & $\begin{array}{l}>2000 \mathrm{PhP} \\
(>\$ 42 \text { USD) }\end{array}$ & Credit card & One-on-one & $\begin{array}{c}\text { Fully } \\
\text { airconditioned }\end{array}$ & QR code & 6 a.m. to 10 p.m. & $\begin{array}{l}\text { Premium } \\
\text { service }\end{array}$ & 0.035 & 11 \\
\hline 10 & $\begin{array}{l}\text { 1001-2000 PhP } \\
(\$ 21-\$ 41.50 \mathrm{USD})\end{array}$ & Cash & Many-to-one & $\begin{array}{c}\text { Fully } \\
\text { airconditioned }\end{array}$ & Manual & 9 a.m. to 9 p.m. & $\begin{array}{l}\text { Premium } \\
\text { service }\end{array}$ & 0.179 & 4 \\
\hline 11 & $\begin{array}{l}\text { 1001-2000 PhP } \\
\text { (\$21-\$41.50 USD) }\end{array}$ & Credit card & One-to-many & $\begin{array}{c}\text { Fully } \\
\text { airconditioned }\end{array}$ & QR code & $24 \mathrm{~h}$ & VIP service & 0.156 & 6 \\
\hline 12 & $\begin{array}{l}\text { 1001-2000 PhP } \\
\text { (\$21-\$41.50 USD) }\end{array}$ & Cash & One-on-one & Fans & Swipe/tap & 6 a.m. to 10 p.m. & VIP service & 0.320 & 12 \\
\hline 13 & $\begin{array}{l}<1000 \mathrm{PhP} \\
(<\$ 20 \text { USD })\end{array}$ & Cash & One-to-many & $\begin{array}{c}\text { Mixed } \\
\text { ventilation }\end{array}$ & Manual & 6 a.m. to 10 p.m. & $\begin{array}{l}\text { Regular } \\
\text { service }\end{array}$ & 0.044 & 13 \\
\hline 14 & $\begin{array}{l}>2000 \mathrm{PhP} \\
(>\$ 42 \text { USD) }\end{array}$ & Cash & One-on-one & $\begin{array}{c}\text { Fully } \\
\text { airconditioned }\end{array}$ & Manual & 9 a.m. to 9 p.m. & VIP service & 0.086 & 14 \\
\hline 15 & $\begin{array}{l}>2000 \mathrm{PhP} \\
(>\$ 42 \text { USD) }\end{array}$ & $\begin{array}{l}\text { Online } \\
\text { payment }\end{array}$ & One-to-many & $\begin{array}{c}\text { Fully } \\
\text { airconditioned }\end{array}$ & Swipe/tap & 9 a.m. to 9 p.m. & $\begin{array}{l}\text { Regular } \\
\text { service }\end{array}$ & -0.244 & 15 \\
\hline 16 & $\begin{array}{l}<1000 \mathrm{PhP} \\
(<\$ 20 \mathrm{USD})\end{array}$ & Credit card & Many-to-one & Mix & Swipe/tap & $24 \mathrm{~h}$ & $\begin{array}{l}\text { Premium } \\
\text { service }\end{array}$ & 0.117 & 7 \\
\hline 17 & $\begin{array}{l}<1000 \mathrm{PhP} \\
(<\$ 20 \text { USD })\end{array}$ & Cash & One-on-one & $\begin{array}{c}\text { Fully } \\
\text { airconditioned }\end{array}$ & Manual & $24 \mathrm{~h}$ & $\begin{array}{l}\text { Regular } \\
\text { service }\end{array}$ & 0.289 & 3 \\
\hline 18 & $\begin{array}{l}<1000 \mathrm{PhP} \\
(<\$ 20 \text { USD) }\end{array}$ & Cash & One-to-many & Mix & QR code & 9 a.m. to 9 p.m. & VIP service & 0.055 & 9 \\
\hline 19 & $\begin{array}{l}>2000 \mathrm{PhP} \\
(>\$ 42 \mathrm{USD})\end{array}$ & Credit card & Many-to-one & Fans & Manual & 9 a.m. to 9 p.m. & VIP service & -0.479 & 21 \\
\hline 20 & $\begin{array}{c}\text { 1001-2000 PhP } \\
\text { (\$21-\$41.50 } \\
\text { USD) }\end{array}$ & Credit card & One-on-one & $\begin{array}{c}\text { Mixed } \\
\text { ventilation }\end{array}$ & Swipe/tap & 9 a.m. to 9 p.m. & $\begin{array}{l}\text { Regular } \\
\text { service }\end{array}$ & -0.131 & 16 \\
\hline 21 & $\begin{array}{c}\text { 1001-2000 PhP } \\
\text { (\$21-\$41.50 } \\
\text { USD) }\end{array}$ & $\begin{array}{l}\text { Online } \\
\text { payment }\end{array}$ & One-to-many & $\begin{array}{c}\text { Mixed } \\
\text { ventilation }\end{array}$ & Manual & 6 a.m. to 10 p.m. & $\begin{array}{l}\text { Premium } \\
\text { service }\end{array}$ & 0.002 & 14 \\
\hline 22 & $\begin{array}{l}>2000 \mathrm{PhP} \\
(>\$ 42 \text { USD) }\end{array}$ & Cash & One-to-many & Fans & Swipe/tap & $24 \mathrm{~h}$ & $\begin{array}{l}\text { Premium } \\
\text { service }\end{array}$ & -0.163 & 17 \\
\hline
\end{tabular}

\section{Discussion}

The results indicated in Table 4 showed that the most important attribute that the gym-goers considered was the Price of the membership (21.59\%). It could be seen that gym- 
goers preferred the least cost of less than $1000 \mathrm{PhP}$ (\$20 USD), followed by 1001-2000 PhP (\$21-41.50 USD), and least preferred the price greater than $2000 \mathrm{PhP}$ (\$42 USD). As indicated by Mordor Intelligence [6], people would be willing to spend on their training and fitness needs. However, given the options, it could be seen that gym-goers would still want a cheaper price for the service. Kosenko and Rahtz [37] and Rao and Sieben [38] found out that with knowledge for price range, consumers would tend to go where the price is lower and offers at par services. This can be further supported by Lichtenstein et al. [64] who stated that price is inversely proportional to the service consumer wants to receive. In the sense of this study, gym-goers would tend to obtain a price range that is reasonable for their fitness means. As practiced, gym-goers know what their fitness goals are and would choose fitness centers that may cater to their needs. Price would be the first thing gym-goers would consider, since fitness centers have standard equipment for different personal purposes, such as treadmills and weights.

The second highest attribute that gym-goers considered was Ventilation (17.56\%). Fully airconditioned was most preferred followed by two levels not preferred being mixed (fans and airconditioned) with fans only as of the least preferred. Blocken et al. [39] identified that gym-goers when working out release continuous amount of carbon dioxide, even while resting. People would tend to perspire a lot during working out and would tend to rest to regain strength. This is one reason why people would prefer airconditioned centers to feel comfortable during their sessions. Ramos et al. [40] also indicated that control strategies are needed to potentiate the benefits of physical activity. Blocken et al. [39] also indicated that even with high levels of danger due to COVID-19 particles present for people who are infected, there are currently high-performing airconditioned rooms or ventilation available in fitness centers. This may be the reason why gym goers would prefer to have a fully airconditioned room rather than mixed ventilation or with fans.

The third highest attribute was Service $(16.69 \%)$. Among the services offered, gymgoers preferred VIP, then premium, and having regular services offered to be least considered. Woolf [41] indicated that gym-goers prefer to have special bundles or special offers from the fitness center. It can be seen from the result that gym goers prefer to have VIP services. In addition, Woolf [41] found out that gym-goers desire to obtain distinct bundles of services among other gym-goers. Garcia-Fernandez et al. [9] also indicated that service convenience and quality affect gym-goer's satisfaction. Therefore, gym-goers would tend to want the VIP service to feel satisfied.

The fourth attribute the gym-goers considered was Trainer (14.63\%). One-on-one was most preferred by gym-goers while many-to-one and one-to-many were not preferred. Even with IHRSA [3] stating that Millennials and Generation Z would want to be in groups, the result showed that gym goers still prefer to have trainers one-on-one. One-on-one service by the trainer gives customer satisfaction by being able to focus on their needs [7]. The one-on-one service by the trainer could also build a relationship with consumers and employees. This is said to be a significant mediator towards positive consumer behavior [65]. This would lead to a high satisfaction level among gym-goers.

The fifth attribute was Payment Method (11.95\%). Cash and online payment had almost the same utility values while credit card was found as the least preferred. Credit card payment was the least preferred due to security reasons. According to Chen et al. [66], cash is still the strongest point-of-sales in any country. However, the emergence of online payment is also being utilized by many. Online payments are already being utilized by the majority in many countries [42]. In addition, Szumski [43] indicated that frequency of operation and security trust are the key points for the utilization of online payments. These findings support the study as to why cash and online payment are almost the same when it comes to payment method preference. However, security with credit cards is still an issue nowadays. Dornadula and Geetha [44] stated that online fraud with prominent use of credit cards is frequent. This has led to people not utilizing credit cards frequently, which also can be seen from the results of this study. 
Interestingly, the sixth and seventh attribute had almost the same utility scores, namely Login $(8.78 \%)$ and Operating Hours $(8.90 \%)$. Among logins, the swipe/tap was the most preferred, followed by QR code, and manual logins. Both QR code and manual logins were seen to be least preferred, having negative utility values. Swipe/tap logins are faster and safer. In the Philippines, the swipe/tap logins direct the details in the main server of the platform of fitness centers. Li et al. [45] stated that automated logins need high security to protect the personal information of the user. However, the swipe/tap logins in the fitness center usually contain information such as full name and membership, and no other personal information is available. On the other hand, manual logins are not preferred since writing down the information requires effort and time. The least preferred is seen to be the utilization of QR codes. Focardi et al. [46] stated that QR codes are prone to malicious websites or infection of smartphones. Moreover, security is a challenge over the internet. Therefore, like credit cards, it could be seen that security is one reason why QR codes are least likely preferred.

With Operating Hours, it could be seen that people prefer $24 \mathrm{~h}$, followed by 6 a.m. to 10 p.m., with 9 a.m. -9 p.m. as the least preferred. From the demographics, it could be seen that most are students or full-time employees. This means that most are working or are in class. In the Philippines, the common time for students is from 7 a.m. -5 p.m. on average, while working-class are from 8 a.m.-6 p.m. or an average of $43.2 \mathrm{~h}$ per week [67]. This is the reason why most of the respondents prefer to have $24 \mathrm{~h}$ operation for fitness centers so the schedule they have would not be compromised.

Overall, the combination from the results of the study showed that gym-goers would prefer services that are cost-effective and at the same time have special offers with VIP services, one-on-one training, fully airconditioned, cash or online payment, utilization of swipe/tap login, and with 24 h operation. This shows that to satisfy customers' preferences, comfortability and security should be the priority of fitness centers [68]. Moreover, the satisfaction of gym-goers will promote consumer-employee relationship and will have positive consumer behavior [63]. This may eventually enhance customer loyalty and motivation to stay in the fitness center [69-76].

Moreover, it could be deduced that the new normal being considered in the current COVID-19 pandemic has led businesses to have new strategies. With that, to have a sustainable business, the preference of the customers during the COVID-19 pandemic should be taken into consideration. The knowledge obtained from this study would help managers and business owners create new strategies in the new situation all businesses are in. This study only considered the environment of fitness centers, but the results indicate that conjoint analysis would still be a great tool to evaluate preferences despite the new normal conditions. Applying the model considered by Geissdoerfer et al. [52], business owners and managers should be proactive in managing a business to have sustainability during and even after the COVID-19 pandemic. Their study utilized the framework to highlight how monetary and non-monetary values would be a long-term perspective for a business. With the findings of this study, it could therefore be deduced that in order for businesses to continue, specifically fitness centers, despite the COVID-19 pandemic, the fitness centers' prices, services, ventilation, trainers, and payment method should be considered.

\section{Conclusions}

The number of fitness centers has increased throughout the years [47]. Along with the increase of the fitness centers are the significant increases of gym-goers, including several studies related to fitness centers and gym-goers [76-82]. The purpose of this study was to analyze the preference of gym-goers during the COVID-19 pandemic in the Philippines by utilizing the conjoint analysis approach. With that, the 22 stimuli were created utilizing a conjoint analysis by orthogonal design. This was done to measure the preference and attributes of fitness centers. 
Among the attributes considered, it was seen from the results that Price was the highest attribute considered (21.59\%), followed by Ventilation (17.56\%), Service (16.59\%), Trainer (14.63\%), Payment Method (11.95\%), Operating Hours (8.90\%), and Login (8.70\%). Gym goers considered the least price of less than $1000 \mathrm{PhP}(<\$ 20 \mathrm{USD})$ with fully airconditioned fitness center having to pay in cash or online. This showed that comfortability with cost-effective services is preferred by customers. Moreover, one-on-one with the trainer, swipe/tap login, with VIP services are preferred by gym-goers. This showed how gym-goers prioritize their security as well. Lastly, $24 \mathrm{~h}$ operating service are the preference of gym-goers, showing that flexibility of fitness centers for their customer should also be considered. Since gym-goers are willing to allocate time for their fitness goals, fitness centers could capitalize on this.

Results also indicated that comfort, security, and fitness center services were the main aspects that gym-goers consider as their main preference. Having to meet these criteria may enhance customer satisfaction and eventually lead to customer loyalty [31,59]. It could be deduced that fitness enthusiasts still consider their comfort even with all the precautions set due to the COVID-19 pandemic. The constant sanitation, social distancing, and scheduling that is present in the fitness centers are acceptable. The results of this study highly emphasized that gym-goers are more sensitive on the Price the fitness centers are implementing. Though customers are sensitive towards prices, proper timing and a reasonable price range may compensate for the set price range. As indicated by the study of Faulkner et al. [15], highlighting incentives may be appealing to consumers in fitness centers. Thus, fitness centers may take advantage of promotions and incentives for the benefit of their branches.

With the COVID-19 pandemic being a transmittable virus, ventilation was highlighted to be the second most important attribute that consumers highlighted. It could therefore be deduced that comfort and health security are being taken into consideration by gym-goers. In line with this, the size of the fitness center has been considered the third highest, which is in line with the second attribute considered.

With that, the trainer and payment method were also high attributes among the preference of customers. These are aligned with the services that fitness centers offer. Therefore, fitness centers should highlight more on the different aspects during promotion to gain the trust and attention of gym-goers. Having these attributes considered as preference of gym-goers could pave the way to obtain more fitness enthusiasts.

In addition, this can be a good marketing strategy to promote gym-goers. The outcome of this study could benefit fitness centers and increase their business market by considering the preferences of customers. The results of this study may be utilized by fitness centers to promote a generalized fitness center for gym-goers of different generations during and even after the pandemic. This highlights how fitness centers are sustainable among different age groups, careers, and even socioeconomic statuses. Moreover, the attributes considered may be applied to other service-centered establishments to promote their market and eventually, revenue.

\subsection{Theoretical Contributions}

The results of this study are great from a marketing standpoint. Comfortability, security, and affordability while meeting their desired needs can promote customer satisfaction and loyalty. The conjoint analysis utilized in this study can be considered by other service providers as well. For further exploration, other attributes may be considered such as fitness goals, equipment needs, and type of workout. This would then be beneficial to extend a holistic and overall fitness center for its consumer.

\subsection{Practical Applications}

The study was able to measure the preferences of gym-goers. It could be seen that even after the COVID-19 pandemic, the desire for gym users will still be applicable. The price should be the focus of the fitness center while being able to cater to customer fitness 
goals. In addition, trainers that can provide one-on-one training can also enhance the fitness center image. Moreover, it could be seen that investment in ventilation is also important, together with the services they provide for the members. From a managerial standpoint, investment in these high attribute scores could lead to customer satisfaction.

\subsection{Limitations}

This study has different limitations. First, the study measured only the general preference available in all gym types. There are different demographics and markets for different gym types, which should be taken into consideration. However, since this is the first study that considered the preference of gym-goers towards fitness centers, the researchers opted to consider general attributes of fitness centers.

Second, this study was conducted during the COVID-19 pandemic and therefore led to the lower number of respondents. Since this study considered those who are only willing to go to the gym even with the COVID-19 pandemic, it gave a clear view of what the gym-goers may want in a fitness center. It is highly recommended to conduct the study after the COVID-19 pandemic.

Lastly, the setting of this study was in the Philippines, wherein the aspect of the attributes such as prices, payment method, and trainers may differ in other countries. It would be best to consider these attributes with levels depending on the country the respondents are in. However, this result still showed how the gym-goers would prefer reasonable prices (applicable to any type of customer) and training being one-on-one rather than in groups.

Author Contributions: Conceptualization, A.K.S.O., Y.T.P., K.L.P. and K.A.S.; methodology, A.K.S.O., Y.T.P., K.L.P. and K.A.S.; software, A.K.S.O., Y.T.P., K.L.P. and K.A.S.; validation, B.A.M., Y.B.K., T.C., R.N. and A.A.N.P.R.; formal analysis, A.K.S.O. and Y.T.P.; investigation, A.K.S.O. and Y.T.P.; resources, K.L.P. and K.A.S.; data curation, Y.T.P.; writing-original draft preparation, A.K.S.O. and Y.T.P.; writing-review and editing, B.A.M., Y.B.K., T.C., R.N., Y.B.K. and A.A.N.P.R.; visualization, Y.T.P.; supervision, Y.T.P., M.N.Y. and R.N.; project administration, Y.T.P.; funding acquisition, M.N.Y. and Y.T.P. All authors have read and agreed to the published version of the manuscript.

Funding: This research was funded by Mapúa University Directed Research for Innovation and Value Enhancement (DRIVE).

Institutional Review Board Statement: Not applicable.

Informed Consent Statement: Informed consent was obtained from all subjects involved in the study.

Data Availability Statement: The data presented in this study are available upon request from the corresponding author.

Acknowledgments: The authors would like to thank all the respondents who participated in this study. The authors would also like to thank Pound for Pound Fitness Philippines for allowing the authors to gather data inside the gym.

Conflicts of Interest: The authors declare no conflict of interest.

\section{References}

1. Tu, R.; Hsieh, P.; Feng, W. Walking for fun or for "likes"? The impacts of different gamification orientations of fitness apps on consumers' physical activities. Sport Manag. Rev. 2019, 22, 682-693. [CrossRef]

2. Angulo, J.; El Assar, M.; Bustos, A.; Rodriguez-Manas, L. Physical Activity and exercise: Strategies to manage frailty. Redox Biol. 2020, 35, 101513. [CrossRef]

3. IHRSA. 2019 Fitness Industry Trends Shed Light on 2020 \& Beyond. 2020. Available online: https://www.ihrsa.org/improveyour-club/industry-news/2019-fitness-industry-trends-shed-light-on-2020-beyond/ (accessed on 2 July 2021).

4. Gough, C. Health \& Fitness Clubs-Statistics \& Facts. 2021. Available online: https://www.statista.com/topics/1141/healthand-fitness-clubs / (accessed on 2 July 2021).

5. Cabalza, C. A Comparative Study of Gyms in the Philippines. 2014. Available online: https://www.academia.edu/11365809/A_ Comparative_Study_of_Gyms_in_the_Philippines (accessed on 17 June 2021). 
6. Mordor Intelligence. Health And Fitness Club Market Size-Growth, Trends, Covid-19 Impact, And Forecasts (2021-2026). 2020. Available online: https:/ / www.mordorintelligence.com/industry-reports/health-and-fitness-club-market (accessed on 20 June 2021).

7. Avourdiadou, S.; Theodorakis, N.D. The development of loyalty among novice and experienced customers of sport and fitness centres. Sport Manag. Rev. 2014, 17, 419-431. [CrossRef]

8. Bagir, S.; Altintig, A. The Reasons for Preference of the Fitness Centres in the Sakarya Region and the Expectations of the Individuals. Procedia Soc. Behav. Sci. 2014, 143, 83-87. [CrossRef]

9. Hooker, S.A.; Ross, K.M.; Ranby, K.W.; Masters, K.S.; Peters, J.C.; Hill, J.O. Identifying groups at risk for 1-year membership termination from a fitness center at enrollment. Prev. Med. Rep. 2016, 4, 563-568. [CrossRef]

10. Global Business Outlook. The Philippines Enters Recession Amid COVID-19 Pandemic. 2020. Available online: https://www. globalbusinessoutlook.com/philippines-enters-recession-amid-covid-pandemic/ (accessed on 17 July 2021).

11. Aguilar, K. Gyms, Tutorial Centers, Grooming Services Can Reopen in GCQ Area by Tuesday (1 September 2020). 2020. Available online: https:/ / newsinfo.inquirer.net/1329244/gyms-tutorial-centers-grooming-services-can-reopen-in-gcq-areas-startingTuesday (accessed on 20 July 2021).

12. Garcia-Fernandez, J.; Galvez-Ruiz, P.; Fernandez-Gavira, J.; Velez-Colon, L.; Pitts, B.; Bernal-Garcia, A. The effects of service convenience and perceived quality on perceived value, satisfaction and loyalty in low-cost fitness centers. Sports Manag. Rev. 2018, 2, 250-262. [CrossRef]

13. Ruotsalainen, I.; Gorbach, T.; Perkola, J.; Renvall, V.; Syvaoja, H.; Tammelin, T.; Karvanen, J.; Parvianinen, T. Physical activity, aerobic fitness, and brain white matter: Their role for executive functions in adolescence. Dev. Cogn. Neurosci. 2020, $42,100765$. [CrossRef]

14. Birch, J. Inclusive fitness as a criterion for improvement. Stud. Hist. Philos. Sci. Part C Stud. Hist. Philos. Biol. Biomed. Sci. 2019, 76, 101186. [CrossRef] [PubMed]

15. Faulkner, G.; Dale, L.P.; Lau, E. Examining the use of loyalty point incentives to encourage health and fitness centre participation. Prev. Med. Rep. 2019, 14, 100831. [CrossRef] [PubMed]

16. Barwitz, N. The relevance of interaction choice: Customer preferences and willingness to pay. J. Retail. Consum. Serv. 2020, 53, 101953. [CrossRef]

17. Hecke, L.; Ghekiere, A.; Cauwenberg, J.V.; Veitch, J.; Bourdeaudhuij, I.D.; Dyck, D.V.; Clarys, P.; Weghe, N.V.D.; Deforche, B. Park characteristics preferred for adolescent park visitation and physical activity: A choice-based conjoint analysus using manipulated photographs. Landsc. Urban Plan. 2018, 178, 144-155. [CrossRef]

18. Kim, D.; Hong, S.; Park, B.-J.; Kim, I. Understanding heterogeneous preferences of hotel choice attributes: Do customer segments matter? J. Hosp. Tour. Manag. 2020, 45, 330-337. [CrossRef]

19. Meyerding, S.G.H.; Bauchrowitz, A.; Lehberger, M. Consumer preferences for beer attributes in Germany: A conjoint and latent class approach. J. Retail. Consum. Serv. 2019, 47, 229-240. [CrossRef]

20. Louviere, J.; Flynn, T.; Carson, R. Discrete Choice Experiments are Not Conjoint Analysis. J. Choice Model. 2010, 3, 57-72. [CrossRef]

21. Mok, M.S.; Sohn, S.Y.; Ju, Y.H. Conjoint analysis for intellectual property education. World Pat. Inf. 2010, 32, 129-134. [CrossRef]

22. Prasetyo, Y.T.; Suzianti, A.; Dewi, A.P. Consumer Preference Analysis on Flute Attributes in Indonesia Using Conjoint Analysis. In Proceedings of the International Conference on Advanced Design Research and Education, ICADRE, Singapore, 16-18 July 2014; pp. 111-117. [CrossRef]

23. Shih, S.P.; Yu, S.; Tseng, H.C. The Study of Consumers' Buying Behavior and Consumer Satisfaction in Beverages Industry in Tainan, Taiwan. J. Econ. Bus. Manag. 2015, 3, 391-394. [CrossRef]

24. Khanna, V. A Study on Factors Impacting Consumer Preference and Purchase Intention: With Special Reference to Beverage Industry. In Proceedings of the 3rd International Conference on Recent Innovations in Science, Technology, Management, and Environment, New Delhi, India, 18 December 2016; Available online: http:/ / data.conferenceworld.in/IFUNA18DEC16/P493-5 12.pdf (accessed on 14 June 2021).

25. Lee, N.; Vega, A. Factors Affecting Consumers' Buying Behavior on Selected Milk Tea Stores Towards Obtaining Sustainability. Cognoscere SPUQC Stud. Res. J. 2014, 9. Available online: https:/ / ejournals.ph/article.php?id=6927 (accessed on 14 June 2021).

26. Pleger, L.E.; Mertes, A.; Rey, A.; Brüesch, C. Allowing users to pick and choose: A conjoint analysis of end-user preferences of public e-services. Gov. Inf. Q. 2020, 37. [CrossRef]

27. Veitch, J.; Salmon, J.; Deforche, B.; Ghekiere, A.; Van Cauwenberg, J.; Bangay, S.; Timperio, A. Park attributes that encourage park visitation among adolescents: A conjoint analysis. Landsc. Urban Plan. 2017, 161, 52-58. [CrossRef]

28. Pinto, D.; Bockenholt, U.; Chang, R.; Sharma, L.; Finn, D.J.; Heinemann, A.; Holl, J.; Hansen, P. Preference for physical activity: A conjoint analysis involving people with chronic knee pain. Osteoarthr. Cartil. 2019, 27, 240-247. [CrossRef]

29. Moore, W.L. A cross-validity comparison of rating-based and choice-based conjoint analysis models. Int. J. Res. Mark. 2004, 21, 299-312. [CrossRef]

30. Ong, A.K.S.; Prasetyo, Y.T.; Libiran, M.A.D.C.; Lontoc, Y.M.A.; Lunaria, J.A.V.; Manalo, A.M.; Miraja, B.A.; Young, M.N.; Chuenyindee, T.; Persada, S.F.; et al. Consumer Preference Analysis on Attributes of Milk Tea: A Conjoint Analysis Approach. Foods 2021, 10, 1382. [CrossRef] 
31. Ong, A.K.; Prasetyo, Y.T.; Young, M.N.; Diaz, J.F.; Chuenyindee, T.; Kusonwattana, P.; Yuduang, N.; Nadlifatin, R.; Redi, A.A. Students' preference analysis on online learning attributes in industrial engineering education during the covid-19 pandemic: A conjoint analysis approach for sustainable industrial engineers. Sustainability 2021, 13, 8339. [CrossRef]

32. Acharaya, B.; Lee, J. User's perspective on the adaptation of e-learning in developing countries: The case of Nepal with a conjoint-based discrete choice approach. Telemat. Inform. 2018, 35, 1733-1743. [CrossRef]

33. Factor, E.M.R.; de Guzman, A.B. Explicating Filipino student nurses' preferences of clinical instructors' attributes: A conjoint analysis. Nurse Educ. Today 2017, 55, 122-127. [CrossRef] [PubMed]

34. Sohn, S.Y.; Ju, Y.H. Conjoint analysis for recruiting high quality students for college education. Expert Syst. Appl. 2010, 37, 3777-3783. [CrossRef]

35. Cameron, T.A.; DeShazo, J.R. Differential Attention to Attributes in Utility-Theoretical Choice Model. J. Choice Model. 2010, 3 , 73-115. [CrossRef]

36. Motta, M. Can a COVID-19 vaccine live up to Americans' expectations? A conjoint analysis of how vaccine characteristics influence vaccination intentions. Soc. Sci. Med. 2021. [CrossRef]

37. Kosenko, R.; Rahtz, D. Buyer Market Price Knowledge Influence on Acceptable Price Range and Price Limit. Assoc. Consum. Res. 1988, 15, 328-331.

38. Rao, A.; Sieben, W. The Effect of Prior Knowledge on Price Acceptability and the Type of Information Examined. J. Consum. Res. 1992, 19, 488. [CrossRef]

39. Blocken, B.; van Druenen, T.; Ricci, A.; Kang, L.; van Hoof, T.; Qin, P.; Xia, L.; Alanis Ruiz, C.; Arts, J.H.; Brombacher, A.C.; et al. Ventilation and air cleaning to limit aerosol particle concentrations in a gym during the COVID-19 pandemic. Build. Environ. 2021, 193, 107659. [CrossRef]

40. Ramos, C.A.; Wolterbeek, H.T.; Almeida, S.M. Exposure to indoor air pollutants during physical activity in fitness centers. Build. Environ. 2014, 82, 349-360. [CrossRef]

41. Woolf, J. Competitive Advantage in the Health and Fitness Industry: Developing Service Bundles. Sport Manag. Rev. 2008, 11, 51-75. [CrossRef]

42. Boden, J.; Maier, E.; Wilken, R. The effect of credit card versus mobile payment on convenience and consumers' willingness to pay. J. Retail. Consum. Serv. 2020, 52, 101910. [CrossRef]

43. Szumski, O. Digital Payment Methods within Polish students-Leading decision characteristics. Procedia Comput. Sci. 2020, 176, 3456-3465. [CrossRef]

44. Dornadula, V.N.; Geetha, S. Credit Card Fraud Detection Using Machine Learning Algorithm. Procedia Comput. Sci. 2019, 165, 631-641. [CrossRef]

45. Li, W.; Tan, J.; Meng, W.; Wang, Y. A swipe-based unlocking mechanism with supervised learning on smartphones: Design and evaluation. J. Netw. Comput. Appl. 2020, 165, 102687. [CrossRef]

46. Focardi, R.; Luccio, F.; Wahsheh, H. Usable security for QR code. J. Inf. Secur. Appl. 2019, 48, 102369. [CrossRef]

47. León-Quismondo, J.; García-Unanue, J.; Burillo, P. Best Practices for Fitness Center Business Sustainability: A Qualitative Vision. Sustainability 2020, 12, 5067. [CrossRef]

48. Mahdi, O.R.; Nassar, I.A. The Business Model of Sustainable Competitive Advantage through Strategic Leadership Capabilities and Knowledge Management Processes to Overcome COVID-10 Pandemic. Sustainability 2021, 13, 9891. [CrossRef]

49. Sahabuddin, M.; Tan, Q.; Hossain, I.; Alam, M.S.; Nekmahmud, M. Tourist environmentally responsible behavior and SatisfactionStudy on The World's Longest Natural Sea Beach, Cox's Bazar, Bangladesh. Sustainability 2021, 13, 9383. [CrossRef]

50. Pongsakornrungsilp, S.; Pongsakornrungsilp, P.; Kumar, V.; Maswongssa, B. The art of Survival: Tourism businesses in Thailand recovering from Covid-19 through brand management. Sustainability 2021, 13, 6690. [CrossRef]

51. Sethuraman, R.; Kerin, R.A.; Cron, W.L. A field study comparing online and offline data collection methods for identifying product attribute preferences using conjoint analysis. J. Bus. Res. 2005, 58, 602-610. [CrossRef]

52. Geissdoerfer, M.; Vladimirova, D.; Evans, S. Sustainable business model innovation: A review. J. Clean. Prod. 2018, 198, 401-416. [CrossRef]

53. Sushil; Anbarasan, P. Organization's sustainable operational complexity and STRATEGIC Overview: TISM approach and Asian case studies. Sustainability 2021, 13, 9790. [CrossRef]

54. Yang, M.; Xia, E. A systematic literature review on pricing strategies in the sharing economy. Sustainability 2021, $13,9762$. [CrossRef]

55. Ying, M.; Tikuye, G.A.; Shan, H. Impacts of firm performance on Corporate Social Responsibility Practices: The mediation role of Corporate Governance in Ethiopia corporate business. Sustainability 2021, 13, 9717. [CrossRef]

56. Ahmad, B.; Da, L.; Asif, M.H.; Irfan, M.; Ali, S.; Akbar, M.I. Understanding the antecedents and consequences of service-sales ambidexterity: A motivation-opportunity-ability (MOA) framework. Sustainability 2021, 13, 9675. [CrossRef]

57. Hair, J.F. Multivariate Data Analysis: A Global Perspective; Pearson: Upper Saddle River, NJ, USA, 2010.

58. Wen, B.L.J.; Aun, N.B. Factors Influencing consumers' purchase intention in Klang Valley, Malaysia: A Study of Bubble Milk Tea. BERJAYA J. Serv. Manag. 2020, 13, 29-43. Available online: https://journal.berjaya.edu.my/wp-content/uploads/2020/02/Jan2020_29-43.pdf (accessed on 2 June 2021).

59. Bezhovski, Z. The Future of the Mobile Payment as Electronic Payment System. Eur. J. Bus. Manag. 2016, 8, 2222-2839. Available online: https:/ / core.ac.uk/download/pdf/234627158.pdf (accessed on 2 June 2021). 
60. Acquaviva, J. Strategies for Personal Trainers. ACSM Health Fit. J. 2004, 8, 8-10. Available online: https: / /journals.lww.com/ acsm-healthfitness/Fulltext/2004/03000/Strategies_for_Personal_Trainers.5.aspx (accessed on 5 June 2021). [CrossRef]

61. De Lyon, A.; Neville, R.; Armour, K. The role of business professionals in public health: A review of the literature. Quest 2016, 69, 313-330. [CrossRef]

62. Ambrosino, N. Assisted Ventilation as an aid to exercise training: A mechanical doping? Eur. Respir. J. 2006, 27, 3-5. [CrossRef] [PubMed]

63. Adhatrao, K.; Gaykar, A.; Honrao, V. A Secure Method for Signing in Using Quick Response Codes with Mobile Authentication. Int. J. Stud. Res. Technol. Manag. 2013, 1, 1-11. [CrossRef]

64. Lichtenstein, D.; Bloch, P.; Black, W. Correlates of Price Acceptability. J. Consum. Res. 1988, 15, 243-252. Available online: https:/ / www.jstor.org/stable/2489529?seq=1 (accessed on 7 June 2021). [CrossRef]

65. Kim, K.A.; Byon, K. A mechanism of mutually beneficial relationships between employees and consumers: A dyadic analysis of employee-consumer interaction. Sport Manag. Rev. 2018, 21, 582-595. [CrossRef]

66. Chen, H.; Huynh, K.; Shy, O. Cash versus card: Payment discontinuous and the burden of holding coins. J. Bank. Financ. 2019, 99, 192-201. [CrossRef]

67. Subido, L.K. The Average Filipino Workweeks is the Longest It's Ever Been. 2020. Available online: https://www.esquiremag. $\mathrm{ph} / \mathrm{money}$ /industry/the-average-filipino-workweek-is-the-longest-it-s-ever-been-a00288-20190311 (accessed on 2 June 2021).

68. Song, H.; Byon, K.K. Moderating effect of the power-distance belief on the relationship between employees' service failures and customers' behavioral outcomes in the sport service industry. Int. J. Environ. Res. Public Health 2021, 18, 2488. [CrossRef] [PubMed]

69. Behnam, M.; Sato, M.; Baker, B.J. The role of consumer engagement in behavioral loyalty through value co-creation in fitness clubs. Sport Manag. Rev. 2021, 24, 1-27. [CrossRef]

70. Koutsoubakis, D. A scale for measuring member commitment and integration in fitness services. Int. J. Sport Manag. Mark. 2020, 20,356 .

71. Foroughi, B.; Iranmanesh, M.; Gholipour, H.F.; Hyun, S.S. Examining relationships among process quality, outcome quality, delight, satisfaction and behavioural intentions in fitness centres in Malaysia. Int. J. Sports Mark. Spons. 2019, 20, 374-389. [CrossRef]

72. Chiu, W.; Won, D.; Bae, J.-s. Customer value co-creation behaviour in fitness centres: How does it influence customers' value, satisfaction, and repatronage intention? Manag. Sport Leis. 2019, 24, 32-44. [CrossRef]

73. Cuesta-Valiño, P.; Gutiérrez-Rodríguez, P.; Loranca-Valle, C. Sustainable management of SPORTS Federations: The indirect effects of perceived service on Member's loyalty. Sustainability 2021, 13, 458. [CrossRef]

74. Fernández-Martínez, A.; Murillo-Lorente, V.; Sarmiento, A.; Álvarez-Medina, J.; Nuviala, A. Exercise addiction and satisfaction of fitness center users as precursors to the intention of continuing to engage in physical activity. Sustainability 2020, 13, 129. [CrossRef]

75. Kim, M. Conceptualization of e-servicescapes in the fitness applications and wearable devices context: Multi-dimensions, consumer satisfaction, and behavioral intention. J. Retail. Consum. Serv. 2021, 61, 102562. [CrossRef]

76. García-Fernández, J.; Gálvez-Ruiz, P.; Sánchez-Oliver, A.J.; Fernández-Gavira, J.; Pitts, B.G.; Grimaldi-Puyana, M. An analysis of new social fitness activities: Loyalty in female and Male CrossFit users. Sport Soc. 2019, 23, 204-221. [CrossRef]

77. Happ, E.; Scholl-Grissemann, U.; Peters, M.; Schnitzer, M. Insights into customer experience in sports retail stores. Int. J. Sports Mark. Spons. 2020, 22, 312-329.

78. Escamilla-Fajardo, P.; Alguacil, M.; Gómez-Tafalla, A.M. Effects of entrepreneurial orientation and passion for work on performance variables in sports clubs. Sustainability 2021, 13, 2920. [CrossRef]

79. Gálvez-Ruiz, P.; Conde-Pascual, E.; Estrella-Andrade, A.; García-Fernández, J.; Romero-Galisteo, R.P.; Vélez-Colón, L.; Pitts, B.G Testing factorial invariance of the questionnaire of evaluation of the Quality perceived in sports services in Spanish, Ecuadorian and Colombian users. Curr. Psychol. 2018, 40, 1249-1256. [CrossRef]

80. León-Quismondo, J.; Bonal, J.; Burillo, P.; Fernández-Luna, Á. Walkability and fitness Center Prices, opening hours, and Extra services: The case of Madrid, Spain. Int. J. Environ. Res. Public Health 2020, 17, 5622. [CrossRef]

81. Baena-Arroyo, M.J.; García-Fernández, J.; Gálvez-Ruiz, P.; Grimaldi-Puyana, M. Analyzing consumer loyalty through service experience and service convenience: Differences between instructor fitness classes and virtual fitness classes. Sustainability 2020, 12, 828. [CrossRef]

82. Chang, C.-H.; Robinson, L.; Shu, S.-T.; Ma, S.-C. Fitness innovativeness, duration of stay, and revisit behavior: A moderation relationship. Int. J. Sports Mark. Spons. 2019, 20, 634-645. [CrossRef] 